\title{
YEN LOAN TO KLIA PROJECT: SOCIOECONOMIC IMPACT ON THE SEPANG AND BANDAR ENSTEK AREA ${ }^{1}$
}

\author{
Asmadi Hassan, Mohd Ikbal Mohd Huda, Rohayati Paidi
}

\begin{abstract}
In 1994, the Government of Malaysia received 61.518 million yen to commence Kuala Lumpur International Airport (KLIA) project. The airport is located in the district of Sepang, Selangor, which was originally oil palm plantations and small villages. The construction project completed and began in used in the 1998. This paper is to evaluate the impact of Japan's ODA for Malaysia, particularly yen loan to socioeconomic. In term of socioeconomic impact, many new cities were established such as Bandar Baru Salak Tinggi, Bandar Baru Nilai, Banting, Bandar Enstek and Cyber Jaya. Similarly, new housing, schools, shopping malls and other facilities such as the Sepang International Circuit and Universiti Sains Islam Malaysia (USIM) were built. New roads connecting to the airport also completed the development of these places. In terms of employment, previously many who depended on agriculture, now turned to business, hospitality, services, transportation and others. In fact the huge investment significantly affected the surrounding population, particularly the creation of modern towns, businesses and educational centers which gave rise to various types of employment.
\end{abstract}

Keywords: yen loan, KLIA, urbanization, employment

\section{Introduction}

Financial assistance and economic cooperation from developed to new independent countries are of significant importance for economic development. In the early post-independence era, Malaysia faced challenges of how to resolve socioeconomic problems such as poverty and economic instability. Japan's Official Development Assistance (ODA) ${ }^{2}$ had fulfilled part of the financial needs, especially in the area of funding development projects. The Japanese ODA was channeled to Malaysia after nine years of diplomatic relations between the two nations. ${ }^{3}$ Since then, Malaysia continued to receive ODA from Japan.

On 19 July 1994, Malaysia received a loan of JPY61.518 billion (RM2.19 bilion) to commence the Kuala Lumpur International Airport (KLIA) project. ${ }^{4}$ The airport was located on a large tract of land in Sepang, Selangor, which originally comprised of oil palm plantations, small towns and villages. The construction of the KLIA project was completed in 1998 and the airport was officially opened for commercial use in the same year. The borrower and executing agency

\footnotetext{
${ }^{1}$ We would like to thank The Japan Foundation for generous support for this research.

${ }^{2}$ Official Development Assistance (ODA) is classified as assistance provided by one country to another country in order to assist socioeconomic development of recipient countries. The assistance can be in various forms such as capital, technical assistance and expertise. Refer to Cameron M. Otopalik, "Japan's Overseas Development Assistance: Assessing Conformance with Shifting Priorities," International Journal of Politics and Good Governance, Volume 1, No. 1.1, pg 5-7, Mitsuya Araki "Japan's Official Development Assistance: The Japan ODA Model that Began Life in Southeast," Asia-Pacific Review, Volume 14, No. 2, pg 24-29.

${ }^{3}$ Bronson Percival, "Japan-Southeast Asia Relations: Playing Catch-up with China," A Quarterly E-Journal on East Asian Bilateral Relations, Vol. 8, No. 3, 2006, pg 2.

4 Kuala Lumpur International Airport Construction Project, Report on March 2001 http://www.jica.go.jp/english/our_work/evaluation/oda_loan/post/2001/pdf/e_project 39_all.pdf, Refer to Mohd. Nor Ab. Samad, KLIA Kemegahan Negara, Utusan Malaysia, 26 June 1998.
} 
for the project was Kuala Lumpur International Airport Berhad (KLIAB) ${ }^{5}$ and the repayment of the loan was guaranteed by the Malaysian government. According to report by Japan International Cooperation Agency (JICA), the yen loan covered $75 \%$ of the construction cost of the KLIA main terminal building and the airport terminal complex. ${ }^{6}$ The yen loan which was part of the ODA component bears an interest rate of $3 \%$ and has a 25 -year repayment period.

This paper is to examine the yen loan extended to KLIA project and the socioeconomic impact of the funding on the surrounding area. The implementation of KLIA project has stimulated rapid developments in the surrounding areas such as Sepang, Bandar Baru Salak Tinggi, Bandar Baru Nilai, Banting, Bandar Enstek and Cyberjaya. New developments sprang up such as housing schemes, schools, shopping malls and other facilities, including the Sepang International Circuit (SIC) and Universiti Sains Islam Malaysia (USIM). Many new roads were built connecting the airport to other cities and towns which also complemented the developments of these urban centers surrounding KLIA. The new developments generated lots of business and job opportunities; residents of the surrounding areas whose livelihoods were once dependent on agriculture are now involved in various kinds of commercial activities such as trading businesses, hospitality industry, services and transportation.

\section{Yen Loans to Malaysia}

A yen loan is a type of financial assistance with a low interest rate and a long repayment period, up to 40 years. $^{7}$ The responsible agency to channel the assistance is Japan Bank for International Cooperation (JBIC). ${ }^{8}$ Yen loans to Malaysia have financed 74 projects in six sectors, namely electricity and gas, transportation, social services, mining and manufacturing, agriculture and fisheries, and telecommunications. ${ }^{9}$ From the years 1966 to 2010, a total of JPY917,113 billion ${ }^{10}$ (USD1,242.45 million) or $45 \%$ of the total number of Japanese ODA schemes channeled to Malaysia were in the form of yen loans. Table 1 shows a complete list of Malaysian projects funded by yen loans from the years 1969 to 2010 .

\footnotetext{
${ }^{5}$ KLIAB was established under Ministry of Transport on August 1992 and was fully financed by the Ministry of Fianace in May 1993. http://www.jica.go.jp/english/our_work/evaluation/oda_loan/post/2001/pdf/e_project_39_all.pdf

${ }^{6}$ Op. cit. Mohd. Nor Ab. Samad.

${ }^{7}$ Terms and Conditions of Japanese ODA Loans, accessed on April 2014. http://www.jica.go.jp/english/our_work/types_of_assistance/oda_loans/standard/index.html.

8 "The Revision of the "Oda Charter and Japan's New Approach," Japan ODA White Paper 2003, accessed in April 2014, http://www.mofa.go.jp/policy/oda/white/2003/part1_2_3.html.

${ }^{9}$ Hidekazu Tanaka, "International Cooperation and National Consensus Building," Quarterly Journal of Public Policy \& Management, Mitsubishi UFJ Research and Consulting, Vol. 4, 2010, pg 82.

10 The total equals to USD138.05 million for every five-year development plan in Malaysia.
} 
Table 1: List of Malaysian Projects Funded by Yen Loans 1969-2010

\begin{tabular}{|l|c|c|c|}
\hline \multicolumn{1}{|c|}{ Sector } & $\begin{array}{c}\text { Number of } \\
\text { Project }\end{array}$ & $\begin{array}{c}\text { Total } \\
\text { (Billion Yen) }\end{array}$ & $\begin{array}{c}\text { Percentage } \\
(\mathbf{\%})\end{array}$ \\
\hline Electricity and gas & 32 & 427,689 & 51.8 \\
\hline Transport & 16 & 119,473 & 14.4 \\
\hline Social Services & 13 & 255,336 & 20.0 \\
\hline Mining and Manufacturing & 10 & 98,015 & 11.8 \\
\hline Agriculture and Fisheries & 1 & 10,442 & 1.3 \\
\hline telecommunications & 2 & 6,158 & 0.7 \\
\hline Total & $\mathbf{7 4}$ & $\mathbf{9 1 7 , 1 1 3}$ & $\mathbf{1 0 0 . 0}$ \\
\hline
\end{tabular}

Source: http://www2.jica.go.jp/en/yen_loan/.

The implementations of long-term projects have impacted Malaysia's socioeconomic growth. The development of Putrajaya Administrative Centre is among the best examples of the projects. The opening of the Putrajaya Administrative Centre, located in the Multimedia Super Corridor, not only created a new modern city in Malaysia, but is also an example of a city in the garden, which is equipped with multimedia technology and other modern facilities. Putrajaya has been recognized as an integrated development model with sustainable development for a balance ecosystem. The development of Putrajaya created new settlements, jobs opportunities and positive impacts on the surrounding area.

\section{Kuala Lumpur International Airport}

Sepang was not a well-known area in Selangor prior to the KLIA project commencement on 22 December 1994. The construction was completed in the year 1998 with a conservative estimated cost of about RM9 billion. ${ }^{11}$ The airport, sitting on an area of approximately 10,000 hectares, was officiated by Yang di-Pertuan Agong, ${ }^{12}$ Tuanku Ja'afar on June 30, $1998 .{ }^{13}$

Initially, the proposed KLIA project received a great deal of criticism prior to the construction. First, 400 land owners instituted legal proceedings against the government due to dissatisfaction with the compensations offered for their lands acquired by the authority, while 425 indigenous people from 85 families were unhappy because they were evacuated and received small compensations from the government. Second, problems arose as a number of the 25,000 construction workers were illegal immigrants. Some contractors had employed foreign workers without permits in order to save costs. This problematic situation tarnished the image of KLIA. Third, the contractors of KLIA project faced material shortages, mainly cement and other cement related products. In order to resolve the problem, the government was requested to find ways to increase the cement supply as well as prioritize the materials for the national project. Fourth, the exchange rate of yen appreciated significantly against Malaysian Ringgit. Political observers commented that the appreciation of yen would threaten the country's economy. The situation compelled KLIAB to negotiate with the National Bank and other banks on steps to reduce the risk

\footnotetext{
${ }^{11}$ KLIA Magazine, November 1999, no SPR: 2005/00058, no penerimaan: 2005/0000970, National Archives Malaysia.

${ }^{12}$ KL International Airport, no SPR: 2012/00958, no penerimaan: 2012/0007513, National Archives Malaysia. Refer to Lapangan Terbang Antarabangsa Kuala Lumpur, Ogos 1965, no SPR: 2006/01257, no penerimaan: 2006/0026138, National Archaive Malaysia.

${ }^{13}$ Op. cit. Mohd. Nor Ab. Samad.
} 
Figure 1: Location of KLIA
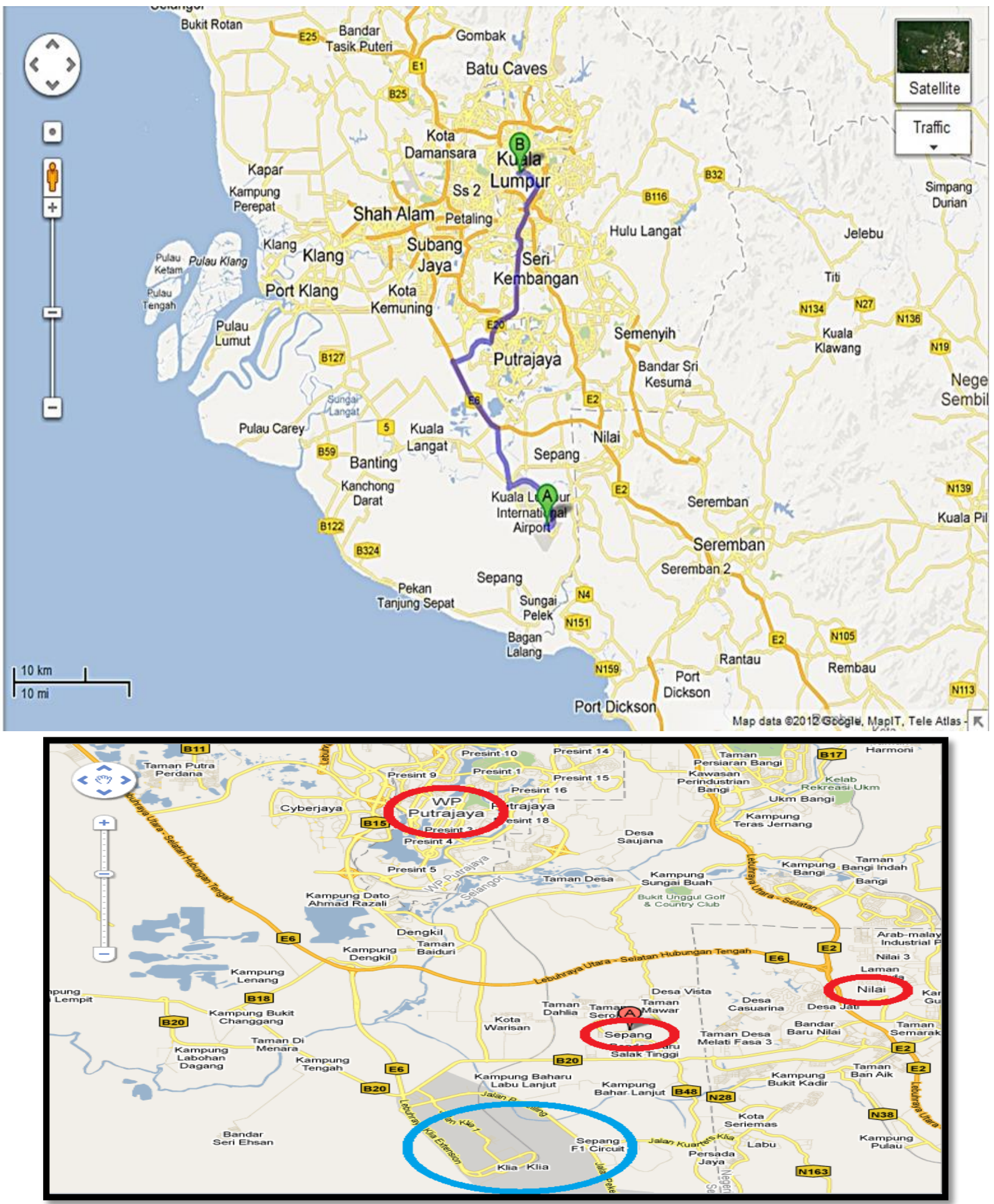

Source: http://www.imtce2016.org/ 
of yen appreciation. Among the measures taken were to swap yen with other currencies. The strategical move was successful in stabilizing the cost of construction to about RM9 billion despite the initial estimated project cost of RM20 billion.

KLIA was opened in 1998, which offers a convenient and comfortable place for air travelers which include individuals, businessmen and women, entertainers and indeed people from all walks of life. ${ }^{14}$ The airport is part of the Multimedia Super Corridor (MSC) equipped with the latest information and communication technology. Figure 1 shows the location of KLIA. The airport's land area is about 100 square $\mathrm{km}$ and is the largest in the world. The vastness of the land area allows the airport operator to expand the facilities such as additional terminals and runways in the future. ${ }^{15}$

KLIA is surrounded by four major cities, namely Kuala Lumpur, Shah Alam, Seremban and Melaka. The concept of developing KLIA is "Airport in the Jungle, Jungle Airport" where it is surrounded by green forest. With the goal of "Bringing the world to Malaysia and Malaysia to the World," KLIA gains recognition from international air travel organizations such as Skytrax and International Air Transport Association (IATA). KLIA's commitment in promoting environmental conservation was rewarded when it received "Green Globe 21" award in the years 2004 and 2005. KLIA became the only airport in the world to receive this recognition. Additionally, KLIA also was the first airport in the world to be awarded the "Airport Service Quality Assured (ASQ)" from the Airports Council International (ACI). KLIA was selected as the leading airport in the category of 15-25 million passengers per year in the year 2005, the award of AETRA in the year 2006 and ACI-ASQ for the years 2006 and 2007. With such excellent service to passengers, it was not surprising that the airport emerged as one of the world's best airports in $2014 .{ }^{16}$

\section{Impact of the KLIA Project}

The proposal to build a new airport to replace Sultan Abdul Aziz Shah Airport in Subang was supported by the government in $1984 .{ }^{17}$ The reason was that the then existing airport was unable to accommodate the rising number of passengers and increasing volume of cargo every year. Various proposals were put forward, including the expansion of the then existing airport. However, due to limited land surrounding the then existing airport, the government decided to build a new airport in Sepang.

The decision to build an airport in Sepang was to boost Malaysia's potential for civil aviation, facilitating higher numbers of aircraft landing and taking off. The airport also had potential for commercial activities since it was designed to incorporate shopping malls, hotels and leisure facilities. The construction of the KLIA project stimulated the socioeconomic development of the surrounding areas. These impacts touched two main aspects of socioeconomic development: urbanization and tourism industry.

\footnotetext{
${ }^{14}$ Op. cit, KLIA Magazine. Also refer to Buku Program Majlis Perasmian Lapangan Terbang Antarabangsa Kuala Lumpur 27 July 1998, no SPR: 2011/00491, no penerimaan: 2011/0004823, National Archives Malaysia.

${ }^{15}$ Op. cit, KL International Airport.

16 "Malaysia's KLIA Ranked the Sixth-Best Airport, Singapore is No.1," The Malay Mail, 21 October 2014.

17 The Making of KLIA (KL International Airport), no SPR: 2006/01113, no penerimaan: 2006/0022278, National Archives Malaysia.
} 


\section{Urbanization}

Urbanization is an indicator to measure the development of an area. Indeed, the KLIA project acted as a catalyst to the process of urbanization of the areas in the vicinity of the airport such as Bandar Baru Salak Tinggi and Cyberjaya (in Sepang), Putrajaya, Bandar Baru Enstek and Nilai (in Negeri Sembilan).

Sepang which was previously among the poorest districts in the state of Selangor had been transformed into a commercial hub with various business activities. ${ }^{18}$ The KLIA project had a direct impact on the urbanization of the nearby areas since the government developed various modes of transportation system to connect other towns and cities with KLIA. The Express Rail Link (ERL), which was built to link Kuala Lumpur to KLIA along 57 kilometers of railroad through the Sepang district, is one of the best examples. The ERL stations located in the Sepang area are Cyberjaya, Putrajaya, Salak Tinggi and KLIA. The development of these stations stimulated commercial growth of the areas, in terms of appreciating land and property values, creation of new jobs resulting from establishments of new businesses, hospitality and leisure industries as well as many other commercial activities.

The rapid Sepang urbanization process was further enhanced by the easy access provided by new and upgraded roads such as highways and free toll modern roads. These roads were built to connect various towns and cities to the airport via Sepang as shown in Figure 2. For example, the Elite Highway in the west, the North South Highway (PLUS Highway) in the East, a federal road B20 in the middle, as well as the South Klang Valley Expressway (SKVE) and Kuala Lumpur-Seremban Highway in the East. All these highways and federal roads were constructed within the district of Sepang and they contributed to the modernization of Sepang.

\section{Figure 2: Roads and Highways to Connect Airport via Sepang}

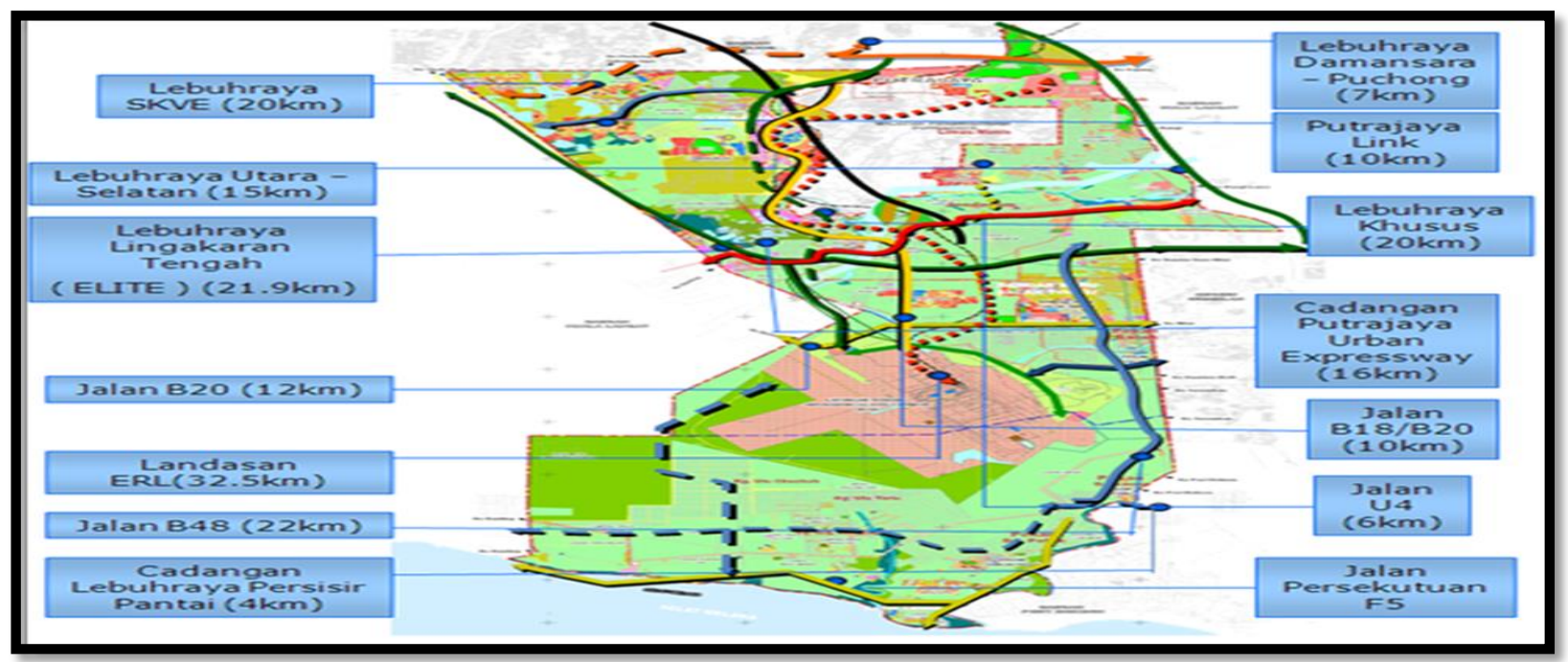

Source: Majlis Perbandaran Sepang

\footnotetext{
${ }^{18}$ Akhbar Ali, "Putrajaya 'Bandar Firdaus," Utusan Malaysia, 30 July 1999.
} 


\section{Figure 3: Accessibility from KLIA to Neighborhood Districts}
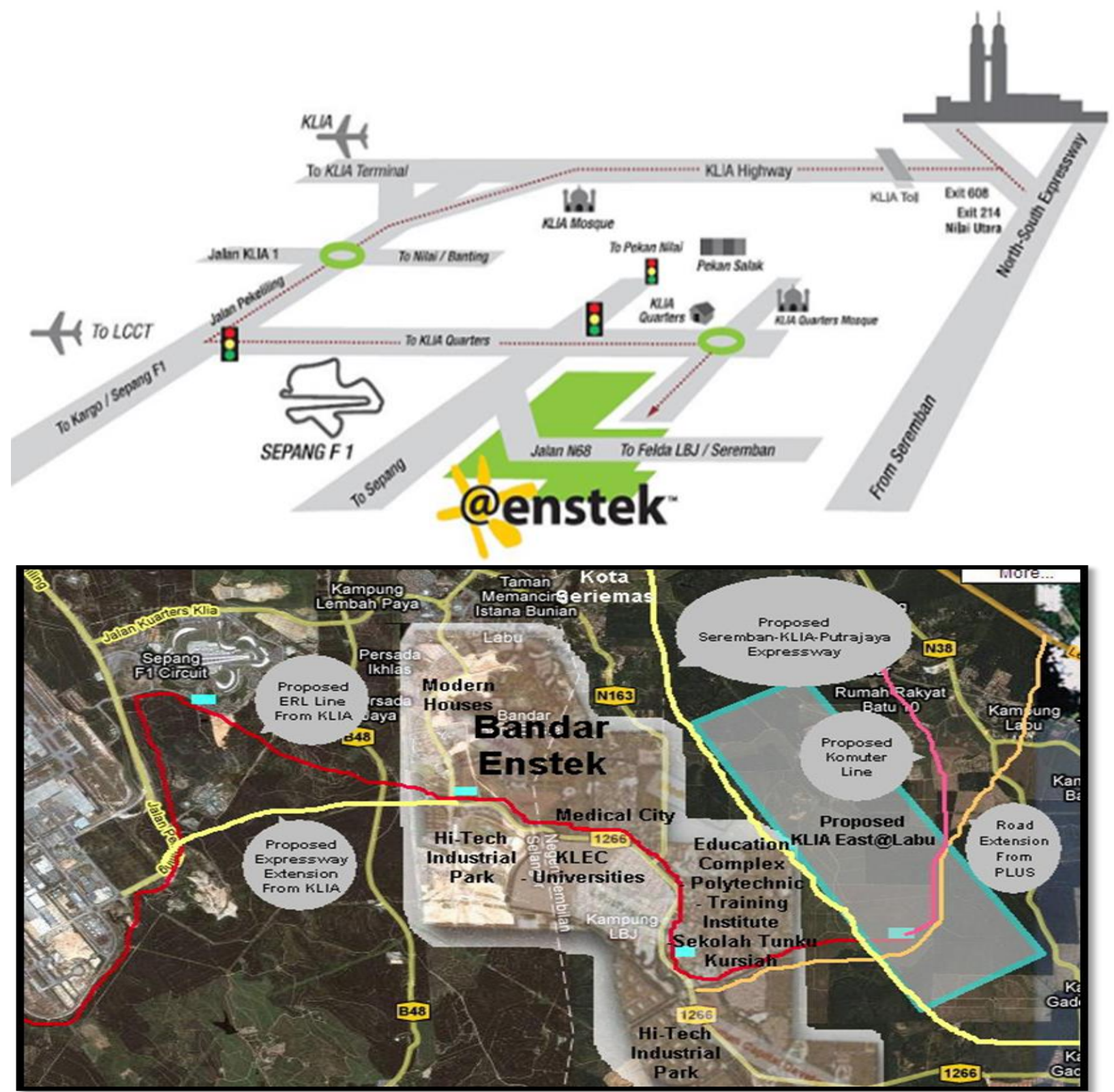

Source: TH Properties. The above shows a breakdown of the distribution of land developments in Bandar Enstek. The commercial projects in Bandar Enstek involve four main components, namely commercial developments, higher education centers, residential areas and industrial areas. 


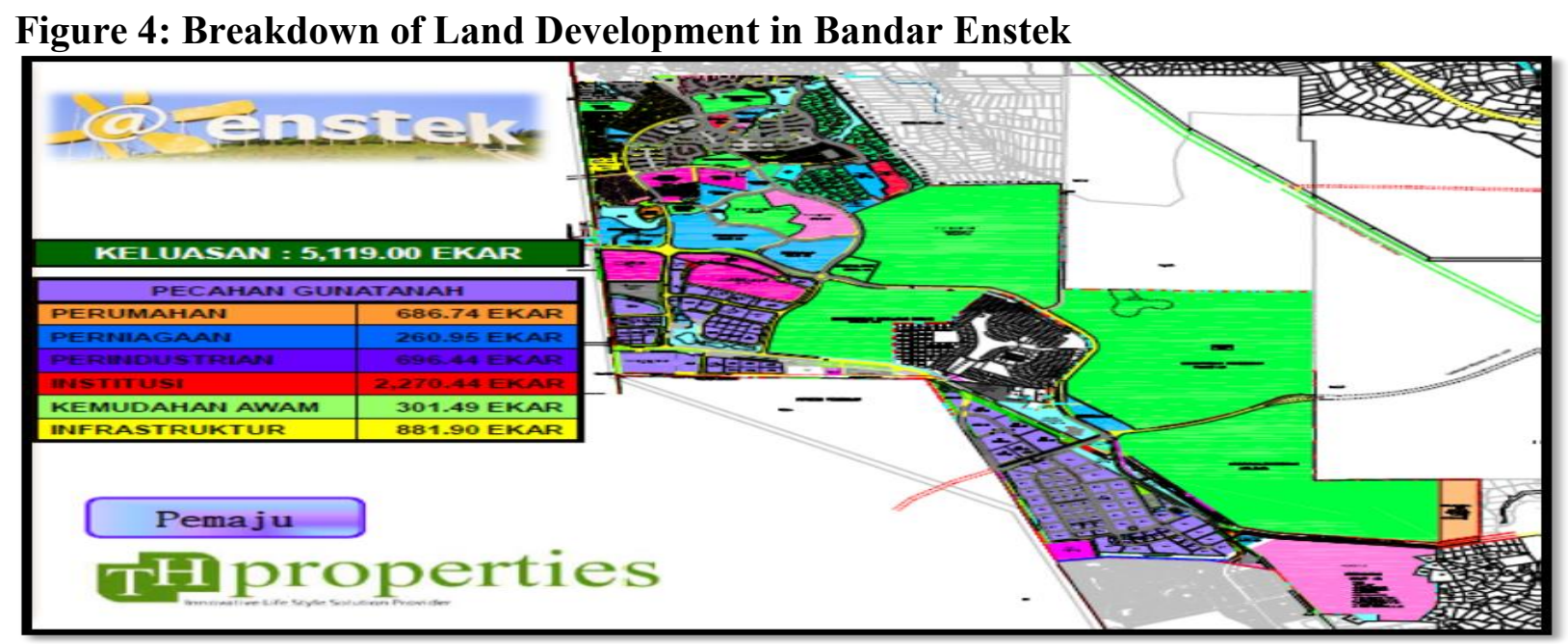

Source: TH Properties

Sepang is the only district in the state of Selangor equipped with international standard facilities such as FI Sepang International Circuit, Sepang Gold Coast and SIC. Its strategic location, adjacent to the government administrative center of Putrajaya has attracted more than 250 investors and 67 Multimedia Super Corridor (MSC) multinational companies operating in Cyberjaya. By the end of the year 2013, large foreign companies that had invested in Cyberjaya were Samsung, Nestle, ALPS, Hitachi Cables, Philip Morris, Dumex, SKF Bearing and Camcar Textron.

The government also implemented new projects such as the KLIA Aeropolis which is an air transportation hub integrated with commercial buildings, hotels, nature conservation zones and green tourism zones. The KLIA area not only serves as a transportation hub but also provides opportunities for development and investment in the sectors of commerce, industry, housing and education.

Besides stimulating overwhelming property, facility and institutional developments in the Sepang district, the economic influence of the KLIA project spilled over to the state of Negeri Sembilan. For example, Bandar Enstek, as shown in Figures 3 and 4 situated just next to the Sepang district, receives much economic stimulus from the KLIA project. Bandar Enstek is developed with a sophisticated communication network and it also offers opportunities for holistic urban growth; this can be attributed to the economic prosperity of its neighborhood areas.

Higher education institutions operating in Sepang and Bandar Enstek are KLIA Professional College and Management, International Islamic University Malaysia (IIUM), Inti International College, Nilai University College and Murni Nursing College. ${ }^{19}$ It is envisaged that in the long term, Sepang and Bandar Enstek will be positioned as a new education and research center with a large number of universities in the locality. For example, the KLIA Professional College and Management offers courses in various fields such as Diploma in Aviation Management and Diploma in Safety and Health. The courses offered at the college are accredited by the Department of Safety and Health and Board of Malaysia Construction and Industry Development. In addition, the college forged a partnership program with the industry and public institutions such as Precast Products Sdn Bhd, KRS Earth (Malaysia) Sdn Bhd, Taisei Corporation, Japan, Universiti Teknologi Malaysia, Universiti Malaysia Perlis, Master Builders Association

\footnotetext{
${ }^{19}$ Siti Nurazlinee Azmi, "Bandar Enstek Penuhi Impian,” Berita Harian, 22 March 2013.
} 
Malaysia, Association of Malay Contractors Malaysia and Association of Contractors Offshore Malaysia. The venture opens up an avenue for the KLIA College instructors to share with others their skills, research and developments as well as practical training experiences. ${ }^{20}$

From the standpoint of investment, Bandar Enstek has, within 10 years, attracted investors such as Pure Circle Sdn Bhd, Felda Biotechnology Centre Sdn Bhd, Holista Biotech, YHI Manufacturing, and Bio Molecular Industries Sdn Bhd. Although Bandar Enstek is located at the fringe of the airport, the town is experiencing vibrant development due to several positive factors such as complete infrastructure and basic facilities, water and electricity supply and advanced ICT and telecommunication networks. These facilities boost the competitive advantage of Bandar Enstek compared with its previous state. ${ }^{21}$

Besides Bandar Enstek, the economic influence of KLIA development spread to several other areas in Negeri Sembilan, leading the state government to launch several high-impact projects such as development of 9,000 acres in Labu and 11,000 acres in Sendayan under the 10th Malaysia Plan. Efficient and convenient highways such as those connecting KLIA with Sendayan, Sungai Gadut with LEKAS Highway, and in Kuala Pilah and Senawang, have attracted companies and international conglomerates to invest and set up operations in the state of Negeri Sembilan.

The foregoing discussions explain the economic spin off of the KLIA project; it benefits not only the immediate Sepang area, but the neighborhood regions which are being transformed into dynamic urban centers and hold great potential for future growth.

\section{Tourism}

Before the establishment of Department of Tourism in 1959, Malaysia's tourism industry was in the doldrums. The government concentrated its efforts in developing the manufacturing sector and the nation was highly dependent on several major commodities such as tin, rubber and palm oil. However, the economic slowdown in the 1980s led the government to switch to other sectors such as tourism, which could rapidly generate economic growth. The tourism industry was identified as a great potential sector that could contribute to the national revenue.

The importance of the industry prompted the government to launch the "Visit Malaysia Year" in 1990. By the year 2005, the tourism industry had become the third largest contributor to the national economy. For the purpose of upgrading the tourism industry, the government spent large sums of money in improving the infrastructure and developing rural areas into popular tourist spots. The Government allocated RM8.801 billion during the Sixth Malaysia Plan and RM18.2 billion during the Seventh Malaysia Plan for these purposes. After the MH370 and MH17 tragedies, the government allocated about RM1.2 billion in 2013 and 2014 to revitalize the tourism industry in Malaysia including the "Visit Malaysia Year" campaign.

According to statistics, there is a very significant increase in the number of tourists coming to Malaysia since the opening of KLIA on June 27, 1998. The numbers of tourists entering Malaysia in subsequent years are as the following: in the year 1998, 6.5 million; 1999, 13.2 million; 2000, 14.8 million; 2001, 14.6 million; 2002, 16.3 million; 2003, 17.5 million; 2004, 21.1 million; 2005, 23.2 million; 2006, 24.6 million; and 2007, 26.5 million. The tourism sector was negatively affected due to two unfortunate events that occurred in the Malaysian travel industry: Flight MH370 disappeared, carrying 329 passengers and crew; and Flight MH17 was shot down. However, the Ministry of Tourism Malaysia promoted the tourism sector aggressively by

\footnotetext{
${ }^{20}$ Nurul Fatiha Muah, “Kolej KLIA Bina Mock-up,” Sinar Harian, 21 June 2014.

${ }^{21}$ Op. cit, Siti Nurazlinee Azmi.
} 
launching the "Visit Malaysia Year 2014", As a result, the number of tourists continued to increase to 28 million. According to the statistics released by KLIAB, nowadays KLIA is capable of handling about 25 million passengers and 650,000 tons of cargo a year. By 2020, KLIAB's goal is to increase the number of passengers to 60 million and the volume of cargo to 1.2 million metric tons per year.

The report issued by the Ministry of Tourism shows that the percentage of revenue from the tourism industry increased from $32.7 \%$ or RM11.2 billion in the year 2000 to $43 \%$ or RM18.1 billion in the year 2005. The increasing number of tourists to Malaysia had contributed to the growth of the domestic economy when revenues exceeded RM57 billion in the year 2010 and RM66 billion in the year 2013. Meanwhile, in the year 2014, the total revenue increased by $12.5 \%$ to RM76 billion. The government is targeting 36 million tourists with revenue of RM168 billion in the year $2020 .^{22}$

KLIA has been identified as the main entrance of tourists to Malaysia before heading to other destinations. As the number of tourists' increases, new economic opportunities are created in the sectors of hospitality and transportation such as buses, taxis and the KLIA Express services.

\section{Socioeconomic Indicators of Achievement}

The KLIA project has positively impacted the surrounding areas in terms of rapid urbanization and flourishing tourism industry. Residents nearby benefited from the airport development in the form of improved socioeconomic wellbeing. Indicators of achievement show tremendous economic contributions in the following areas: building of new settlements, increased household income, appreciating property values and creation of job opportunities.

\section{New Settlements}

The KLIA project attracted migration of people from places all over the country to the surrounding areas. Thus, high population of diverse demographics, especially in Sepang was the direct consequence of KLIA project. As shown in Table 2, the total population in Sepang in the year 2001 was 117.9 thousand. However, this number increased to 207.4 thousand in the year 2010 . The increasing number of the population was associated with the construction of new housing schemes surrounding the KLIA. Most residents living in the vicinity of KLIA work in airline companies and in industrial corporations; all these establishments exist as a result of the airport development.

Among the new settlements developed around KLIA are those in Cyberjaya where MCT Consortium Bhd launched a new housing project worth RM3.6 billion. The developer was willing to invest a large sum of money because of the confidence in house demand from the residents who work in companies close to KLIA. ${ }^{23}$ Another housing project, Salak Perdana, was also developed to meet the demand for housing in the vicinity of KLIA. The Salak Perdana housing project is close to Bandar Baru Salak Tinggi which has 2,000 units of houses catering to the needs of airport employees; it also has a guest house providing accommodation during the Formula 1 race. ${ }^{24}$ Its

\footnotetext{
22 “Airport City Planned Near KLIA," The Star, 13 June 2014.

23 Joseph Chin, "MCT to Unveil RM3.6 Bil Residential Projects," The Star, 17 January 2015.

24 “MCT's Kiss of Life for Salak Tinggi Project," Malaysian Digest, 28 February 2014.
} 
proximity to the airport, about 20 minutes by car, is the main attraction for people to purchase the properties in this housing estate.

Other developers such as IOI Properties, developed 132.8 hectares of land in Kota Warisan, Glomac developed 76.8 hectares of land in Dengkil ${ }^{25}$ and PNSB built 112 shops and offices on 30 acres of land in Bandar Baru Salak Tinggi. ${ }^{26}$ In the future, more settlements will be built due to the rapid development in the surrounding areas of KLIA.

Table 2: Population of Sepang in 2001-2010

\begin{tabular}{|c|c|}
\hline Year & Population ('000) \\
\hline 2001 & 117.9 \\
\hline 2002 & 121.6 \\
\hline 2003 & 125.5 \\
\hline 2004 & 129.6 \\
\hline 2005 & 133.9 \\
\hline 2006 & 138.1 \\
\hline 2010 & 207.4 \\
\hline
\end{tabular}

Source: http://www.selangor.gov.my/sepang.php/pages/view/23;

http://www.statistics.gov.my/portal/download_Population/files/population/05Jadual_Mukim_negeri/Mukim_Selang or.pdf

Along with the development of new settlements, the quality of life improves, with emergence of modern facilities such as schools, health care centers and many others. Based on interviews conducted randomly in Kota Warisan, the majority of residents decided to buy properties in those areas because of the development of KLIA. ${ }^{27}$ Despite some bad smell coming from oil palm plantations in the late 1990s and the noise caused by passing aircrafts, they were determined to purchase the properties. In fact, they argued that purchasing of properties in these areas was the appropriate choice following rapid developments surrounding the KLIA area.

\section{Property Value}

The construction of KLIA boosted the property values in Sepang. For example, prices of land between 45 cents and 70 cents per square foot increased to a level of between RM35 and RM100 per square foot in 2015. Based on random interviews conducted in Kota Warisan, residents in those areas did not expect the values of their properties to soar in less than 10 years. Residents who bought homes in the area at RM350,000 per unit in the mid-2000 found that the current values of their properties have reached as high as RM800,000 to RM1 million even though the area is far from the city center of Kuala Lumpur. ${ }^{28}$

In Bandar Enstek, the price of a two-story terrace house priced at RM138,000 in the year 2000 reached a level of more than RM450,000 in 2015. The increase in property values in Bandar Enstek was also due to its location close to the airport and the development of the area. Although house prices showed a significant increase in 2015, residential units in Bandar Enstek were still acclaimed as dream homes.

\footnotetext{
25 Ibid.

26 Tahun 2014: PNSB terus Memacu Kemajuan, Sinar Harian, 30 January 2014.

${ }^{27}$ Interviews with residents of Kota Warisan on 18 Dicember 2015.

28 Ibid.
} 


\section{Employment and Households Income}

The modern infrastructure in Malaysia is one of the factors that attracts foreign direct investments (FDI). Investors from Japan, the United States, Asian and European countries were among the business people who invested their money in Malaysia. Total FDI flows continued to soar when Malaysia was listed at the 10th place as a destination for FDI in the world in the year 2010. Based on the FDI confidence index survey conducted by a global management consulting firm, E.T. Kearney found that investor confidence for Malaysia was growing as modern and efficient infrastructures were built. In sum, the sophisticated infrastructures have created an environment conducive to investment and the competitiveness of Malaysia was strengthening. ${ }^{29}$

The KLIA project was a catalyst for economic development that benefited residents nearby. ${ }^{30}$ With the increasing number of investments, implementations of new projects by foreign companies, establishments of educational centers and urbanization in Sepang and Bandar Enstek, new job opportunities were created for the residents who previously relied on agriculture as a means of livelihood. In fact, some of the residents switched from farming to engaging themselves in businesses, hospitality industry, services and transportation sector. ${ }^{31}$

For example, the establishment of SIC potentially creates 4,712 new jobs until the year 2020. The KLIA project created new jobs in the operation of hotels, businesses, restaurants and transportation. Similarly, the introduction of KLIA Express offers job opportunities such as operating personnel, sales executives, maintenance staff and other positions. Implementation of KLIA Aeropolis (Airport City) also offers job opportunities to residents nearby. ${ }^{32}$ For example, The Mitsui Outlet Park KLIA which is situated in KLIA Aeropolis area is the largest shopping center in Southeast Asia that provided more than 1,800 jobs in $2014 .{ }^{33}$ The Mitsui Outlet Park KLIA is a shopping destination to 27 million travelers in Malaysia every year; besides that, the shopping center supports the local economy with its scheduled expansion programs. In the year 2018, the operator increased the number of stores from 130 to 190 and will further increase the number to the maximum of 250 in the year 2021. Upon completion in the year 2021, The Mitsui Outlet Park KLIA will provide over 2,500 jobs with a total investment of RM335 million.

In addition, the opening of DPulze Shopping Centre in Cyberjaya also benefits the local residents. DPulze Shopping Centre has a list reputable tenants which include TGV, Jaya Grocer, FOS, Celebrity Fitness, MPH, Yamaha, U Bowl, Song Box, Molly Fantasy, Tune Hotels and Regus; these companies and shopping outlets offer different categories of job opportunities to the local people. ${ }^{34}$

\footnotetext{
29 "Buku Tahunan Daya Saing 2012" (WCY), published by Institute for Management Development (IMD). Accessed via http://www.pemudah.gov.my/c/document_library/get_file?uuid=4aa2de97-81a4-4d85ab2cb45c021b985f\&groupId=172432.

30 "Indeks Kompetitif Global" published by World Bank. Accessed via http://www3.weforum.org/docs/WEF_GlobalCompetitivenessReport_2012-13.pdf on 15 Jun 2013.

${ }^{31}$ Hugh Patrick, "Legacies of Change: The Transformative Role of Japan's Official Development Assistance in its Economic Partnership with Southeast Asia," Discussion Paper No. 54, Discussion Paper Series APEC Study Center, Columbia University, pg 13.

${ }^{32}$ KLIA Aeropolis Set to Put Malaysia on Aviation Map, The Star, 26 January 2015.

${ }^{33}$ Rezwana Manjur, "Malaysia Looks to Become the Next Big Shopping Destination in SEA," Marketing Interactive, 3 August 2015.

${ }^{34}$ Pamella Lim, "New Attraction for Cyberjaya," The Star, 25 April 2014.
} 


\section{Conclusion}

The KLIA project was proposed in the early 1990s when the Sultan Abdul Aziz Shah Airport in Subang was unable to cope with the future air traffic in Malaysia. Upon completion, the KLIA project changed the landscape of the Sepang district as well as the neighborhood area such as Bandar Enstek in Negeri Sembilan. The Sepang district in the southern part of Selangor used to be an isolated region developed with small villages and towns. However, with the completion of the KLIA project, the Sepang district was turned into a vibrant economic neighborhood with the airport as a prestigious national landmark. Based on some studies conducted, there are four significant features or impacts of the KLIA project.

First, the project was viewed as very favorable because the yen loans covered $75 \%$ of the total cost; the interest rate was pegged at a low rate of only $3 \%$ and the loan had a long repayment period of up to 25 years. Without the yen loans, the construction cost would be higher and would be a burden to the Malaysian government.

Second, the KLIA project was successful because it had been designed meticulously taking into account the long-term requirement. Various criteria had been specified in the search for a new airport site; there must be sufficient land area for the construction of the airport and it must be able to accommodate future growth. In addition, the location should not exceed 30 minutes of travelling time from Kuala Lumpur city center. At the same time, the location must meet the conditions of environmental impact assessment (EIA). The KLIA project must also meet the future requirements of the aviation industry in Malaysia, which is expanding rapidly.

Third, the KLIA project overwhelmingly impacted the economic development of Sepang district and the neighborhood areas. The region experienced tremendous socioeconomic growth due to the following developments: construction of roads, highways, railroads and railway stations; creation of new townships, shopping malls, industrial estates and housing schemes; installation of public utilities; investments by companies from home and abroad; and promotion of tourism. The KLIA project and the development of the neighborhood area generated a large number of jobs in the sectors of education, health and businesses and there was a significant improvement in the living standards of local residents. With prudent and long-term development planning, the KLIA project achieved the goal of creating a modern city airport.

Fourth, the KLIA project led to the appreciation of values of properties located in Sepang and the neighborhood areas. After the establishment of KLIA, the property values increased from between 45 cents and 70 cents per square foot to a level of between RM35 and RM100 per square foot. For example, prices of residential and commercial properties in Kota Warisan and Bandar Enstek increased from between RM138,000 - RM350,000 in the year 2000 to RM800,000 today. Although house prices keep increasing, the demand for houses is still very strong. 